UDC 541.13

\author{
P. Daniel Nixon, C. Joseph Kennady
}

\title{
ELECTRODEPOSITION OF MANGANESE-NICKEL OXIDE FILMS FOR SUPERCAPACITOR APPLICATIONS
}

\author{
Karunya Institute of Technology and Sciences, Coimbatore, India
}

\begin{abstract}
Manganese-nickel oxide films were electrodeposited on a stainless steel plate substrate in a bath containing manganese sulfate, nickel chloride and a non-ionic surfactant. The structural, morphological and electrochemical properties of these films were investigated. The X-ray diffraction pattern revealed the grain size of the material and confirmed the presence of manganese oxide and nickel oxide in the films. The preparative parameters, such as potential window, scan rate, bath concentration and numbers of potential cycles, were optimized during potentiodynamic deposition. The cyclic voltammetry was used to study the reduction and oxidation mechanism during the electrodeposition process. The charge-discharge method was applied to study the capacitor property of the synthesized material.
\end{abstract}

Keywords: supercapacitor, oxide electrodes, electrodeposition, surface characterization, cyclic voltammetry, charge-discharge curve.

DOI: $10.32434 / 0321-4095-2019-127-6-144-148$

\section{Introduction}

Supercapacitors received much attention in recent years as a very good solution to meet the increasing demands for energy storage. This is mainly because of their fast power energy delivery, extended life cycle and high power and reasonably high energy density. Due to these properties, supercapacitors can fill the gap between batteries and convention capacitors [1-4].

However, supercapacitors received set back because of its low energy density and high production cost. More new electrode materials are developed in order to overcome the obstacle. Supercapacitors with electrochemically active materials (polymers and metal oxides) as electrodes have been developed. Metal oxides are considered the most promising materials for the next generation of supercapacitors. Noble metal oxides exhibit much higher specific capacitance than conventional carbon materials and better electrochemical stability than electronically conducting polymer materials, such as $\mathrm{RuO}_{2}$ [5-7].

However, the high cost of these noble metal materials limits it from commercialization. Therefore, the development of alternative inexpensive electrode materials with high performance has been one of the most active research fields of electrochemistry during the last few years. Several transition metal oxides and hydroxides have been investigated, e.g. $\mathrm{NiO}$ [8], $\mathrm{CoO}_{x}$ [9], $\mathrm{MnO}_{2}$ [10], $\mathrm{Ni}(\mathrm{OH})_{2}$ [11], $\mathrm{Co}(\mathrm{OH})_{2}[12]$, etc. Manganese and its oxides have received much attention as an alternative to the ruthenium oxide in electrochemical capacitor applications because of their satisfactory electrochemical performance, relatively low cost, natural abundance, and so on $[10,13,14]$.

In the present work, manganese-nickel oxide films were electrodeposited from a bath containing manganese sulfate, nickel chloride and a non-ionic surfactant. The structural, morphological, and electrochemical properties of the electrodeposited manganese-nickel oxide films were determined and discussed.

\section{Materials and methods}

Stainless steel samples of $1 \mathrm{~cm}$ width, $3 \mathrm{~cm}$ height and $0.1 \mathrm{~cm}$ thick were used as a substrate for electrodeposition. The samples were pretreated by dipping in a solution containing $5.0 \mathrm{~mL}$ of concentrated sulfuric and hydrochloric acid each. Time of dipping was 20-30 minutes. The electrolyte was prepared by dissolving $0.05 \mathrm{~mol}(0.37 \mathrm{~g})$ of manganese sulfate and $0.1 \mathrm{~mol}(0.64 \mathrm{~g})$ of nickel chloride in $50 \mathrm{~mL}$ of distilled water. To this solution, $0.01 \mathrm{~g}$ of Pluronic p123 surfactant, a non-ionic surfactant, was added and stirred well. To this 
solution, $0.01 \mathrm{~g}$ of Pluronic p123 surfactant is added and stirred well. Pluronic p123 is a symmetric triblock copolymer comprising polyethylene oxide (PEO) and polypropylene oxide (PPO) in an alternating linear fashion (PEO-PPO-PEO). Its chemical formula is $\mathrm{HO}\left(\mathrm{CH}_{2} \mathrm{CH}_{2} \mathrm{O}\right)_{20}\left(\mathrm{CH}_{2} \mathrm{CH}\left(\mathrm{CH}_{3}\right) \mathrm{O}\right)_{70}\left(\mathrm{CH}_{2} \mathrm{CH}_{2} \mathrm{O}\right)_{20} \mathrm{H}$.

Manganese-nickel oxide layers were electrodeposited using an Electrochemical Workstation -CHI770d. The electrochemical cell consisted of three electrodes, i.e., pre-treated stainless steel acted as a working electrode, platinum wire acted as a counter electrode, and $\mathrm{Ag} / \mathrm{AgCl}$ electrode acted as a reference electrode. The bulk electrolysis was carried out with potentiostatic method by applying a potential of $0.9 \mathrm{~V}$ and the period of deposition was fixed as 60 minutes. All experiments were carried out at room temperature. After electrodeposition, the working electrode was taken out, rinsed with distilled water, and dried at room temperature.

Electrodeposited manganese-nickel oxide electrodes were subjected to the structural and morphological study using X-ray diffraction (XRD) and scanning electron microscopy (SEM). Energy dispersive X-ray analysis (EDX) was used to determine elements that are present in the prepared electrode.

Cyclic voltammetry experiments were carried out with the prepared manganese-nickel oxide electrode using CHI 770d instrument. For cyclic voltammetric experiments, the electrode surface was masked and an area of $0.196 \mathrm{~cm}^{2}$ was exposed to the electrolyte. The constant current charge-discharge behavior of the manganese-nickel oxide electrodes was investigated galvanostatically at a current of $5 \mathrm{~mA}$.

\section{Results and discussion}

Electrodeposition

The electrodeposited $\mathrm{Mn}-\mathrm{Ni}$ oxide films had a regular surface appearance and the weight of the deposits was measured using an electronic balance and found to be approximately $0.023 \mathrm{~g}$. During the electrodeposition process, the oxidation state of $\mathrm{Mn}$ increases from +2 to +4 . Since it is improbable that two electrons are transferred in a single step, the formation of $\mathrm{MnO}_{2}$ from $\mathrm{Mn}^{2+}$ occurs concomitantly with the oxidation of water molecules. The reactions that are taking place are as follows:

$$
\begin{gathered}
\mathrm{Mn}^{4+}+4 \mathrm{H}_{2} \mathrm{O} \rightarrow \mathrm{Mn}(\mathrm{OH})_{4}+4 \mathrm{H}^{+} ; \\
\mathrm{Mn}(\mathrm{OH})_{4} \rightarrow \mathrm{MnO}_{2}+2 \mathrm{H}_{2} \mathrm{O} .
\end{gathered}
$$

The electrodeposition of nickel oxide in an electrolyte containing $\mathrm{Ni}^{2+}$ ions can be represented as follows:

$$
\mathrm{Ni}(\mathrm{OH})_{2}+2 \mathrm{OH}^{-} \rightarrow \mathrm{NiO}_{2}+2 \mathrm{H}_{2} \mathrm{O}+2 \overline{\mathrm{e}} .
$$

\section{Structural and morphological studies}

Electrodeposited $\mathrm{Mn}-\mathrm{Ni}$ oxide electrode was subjected to the structural study using XRD to find the grain size. The grain size of the material was calculated using the Scherer formula for the grain

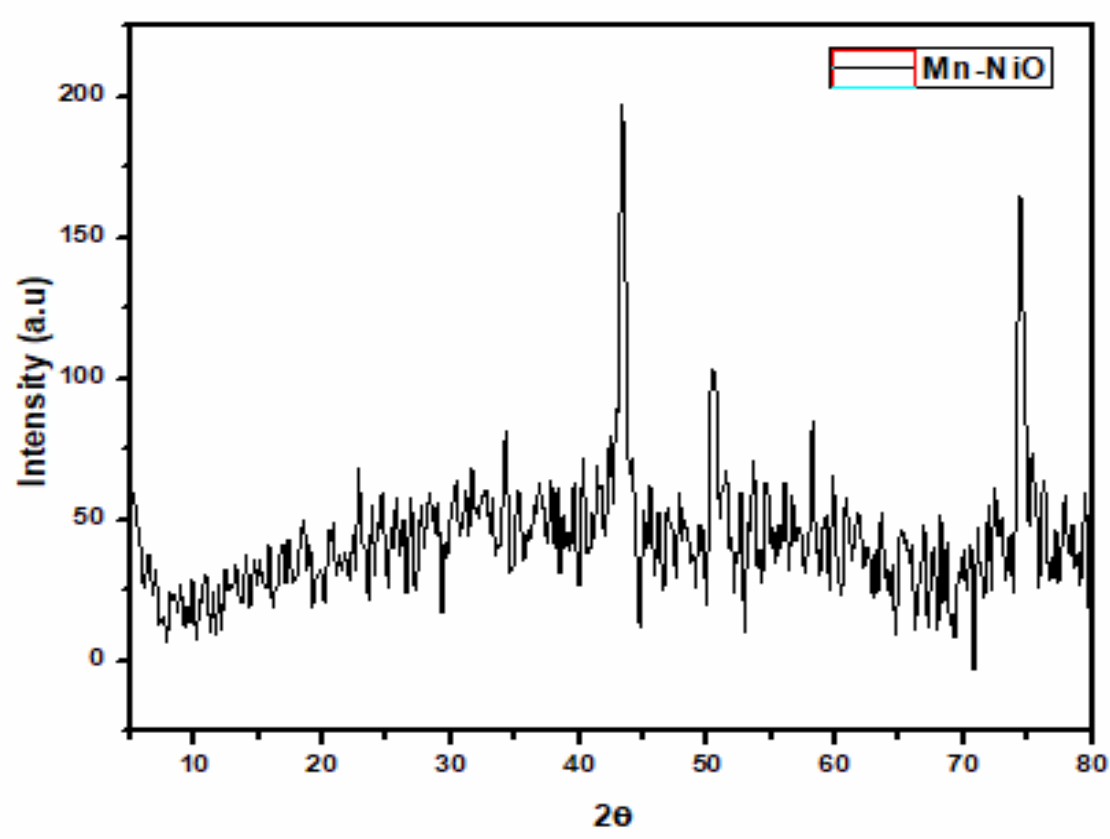

Fig. 1. XRD pattern of the electrodeposited $\mathrm{Mn}-\mathrm{Ni}$ oxide film 
size. From the XRD data (Fig. 1), the grain size of the $\mathrm{Mn}-\mathrm{Ni}$ oxide was found to be in the order of $25 \mathrm{~nm}$. Addition of neutral or non-ionic surfactant helps in achieving nano-structures of oxide films.

The appearance of a diffraction peak at $34^{\circ}$ denotes the presence of manganese oxide and the peak at $43^{\circ}$ denotes nickel oxide. The XRD spectrum suggested that separate manganese oxide and nickel oxide, not in the form of composites, were obtained using the electrodeposition technique.

SEM micrograph (Fig. 2) reveals that the deposited $\mathrm{Mn}-\mathrm{Ni}$ oxide surface is uniform and exhibits minor cracks. Seemingly, the observed porous spaces may enhance the redox behavior of the fabricated oxides layers.

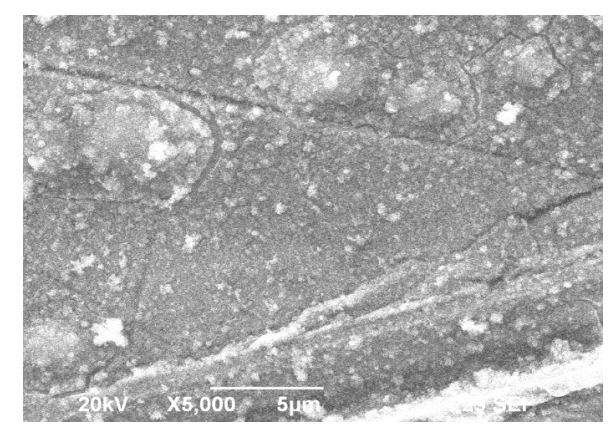

Fig. 2. SEM image of the electrodeposited $\mathrm{Mn}-\mathrm{Ni}$ oxide film

The electrodeposited $\mathrm{Mn}-\mathrm{Ni}$ oxide film was subjected to EDX analysis and the graph (Fig. 3) shows the presence of manganese, nickel and iron, which was the substrate.

\section{Electrochemical study}

Figure 4 shows the cyclic voltammograms (CVs) recorded for the $\mathrm{Mn}-\mathrm{Ni}$ oxide electrode electrodeposited at two different scan rates. CVs were measured from -0.2 to $+1.0 \mathrm{~V}$ (vs. $\mathrm{Ag} / \mathrm{AgCl}$ reference

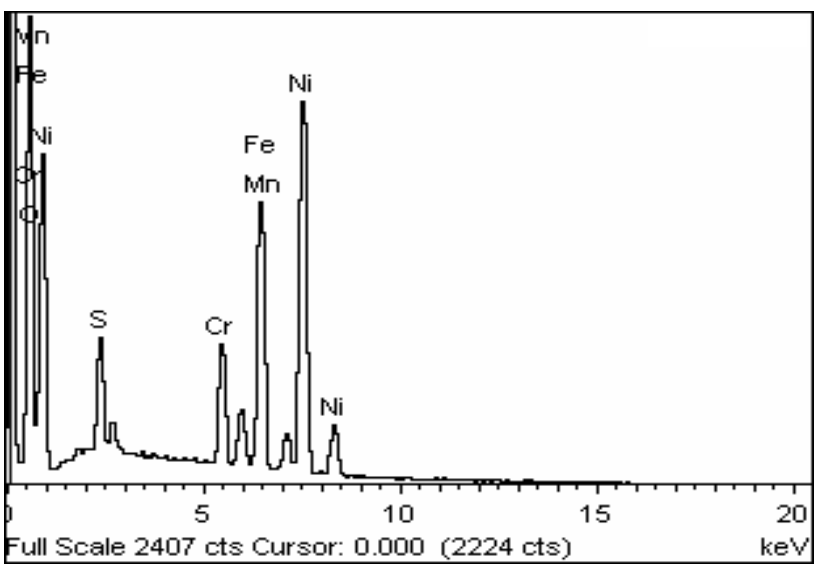

Fig. 3. EDX graph of the electrodeposited $\mathrm{Mn}-\mathrm{Ni}$ oxide films

electrode) in the $0.5 \mathrm{M} \mathrm{Na}_{2} \mathrm{SO}_{4}$ electrolyte. The $\mathrm{CV}$ curve shows clear redox behavior of the electrode by having both anodic and cathodic peak at $+700 \mathrm{mV}$ and $+610 \mathrm{mV}$, respectively. This indicates that the system is a quasi-reversible and this will enhance the charge-discharge characteristic of the electrode when it is used as an electrode in supercapacitors. Figure 4 also shows that the area under the curve increased with the scan rate. This implies that the voltammetric current was proportional to the scan rate, corresponding to a capacitive behavior.

Figure 5 shows the charge-discharge cycle of the electrodeposited $\mathrm{Mn}-\mathrm{Ni}$ oxide electrode. The charge-discharge curve was nearly symmetric in the range between 0 and $1.0 \mathrm{~V}$ (vs. $\mathrm{Ag} / \mathrm{AgCl}$ ), indicating that a good capacitive behavior of the electrodeposited $\mathrm{Mn}-\mathrm{Ni}$ oxide electrode was observed. The calculated specific capacitance value is $91.4 \mathrm{~F} \mathrm{~g}^{-1}$.
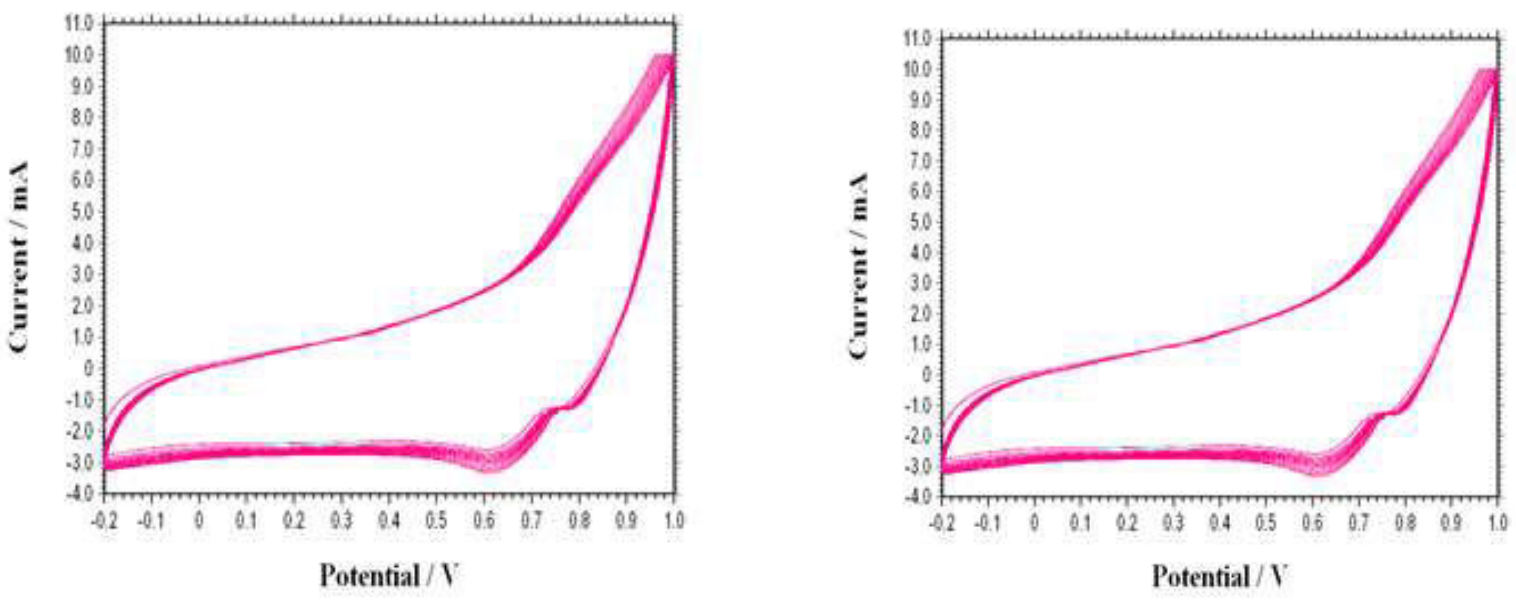

a

b

Fig. 4. Cyclic voltammogram of $\mathrm{Mn}-\mathrm{Ni}$ oxide film in $0.5 \mathrm{M} \mathrm{Na}_{2} \mathrm{SO}_{4}$ electrolyte at a scan rate of $20 \mathrm{mV} \mathrm{s}^{-1}$ (a) and $60 \mathrm{mV} \mathrm{s}$ (b) 


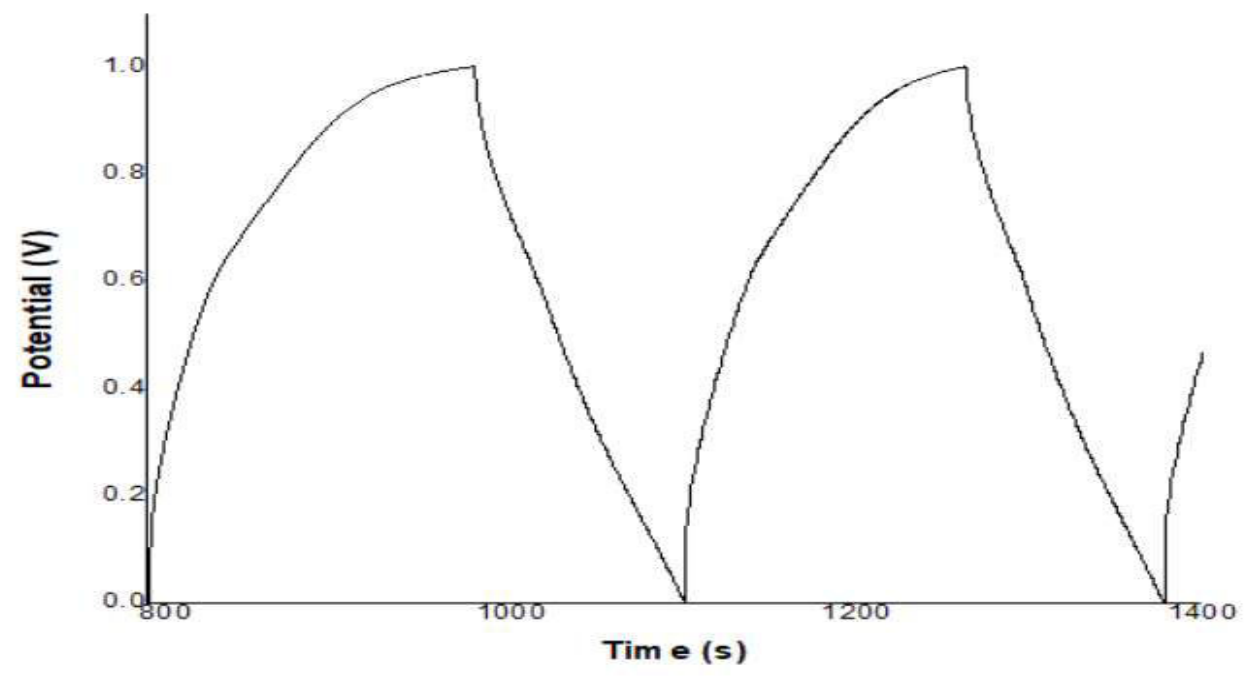

Fig. 5. Charge-discharge curve of the electrodeposited $\mathrm{Mn}-\mathrm{Ni}$ oxide electrode in $0.5 \mathrm{M} \mathrm{Na}_{2} \mathrm{SO}_{4}$

\section{Conclusions}

The electrodeposited $\mathrm{Mn}-\mathrm{Ni}$ oxide electrode was uniform and exhibited some porous morphology, which was evident from SEM study. The grain size of the oxide films was found to be in the order of $27 \mathrm{~nm}$ and the peaks from XRD pattern confirmed the presence of manganese and nickel oxide separately. Cyclic voltammetric study showed that the electrode had a redox behavior and the area under the peaks was increased with increasing the scan rate. This is a favorable pattern for increased charge discharge behavior. The synthesized oxides films gave the specific capacitance value of $91.4 \mathrm{~F} \mathrm{~g} \mathrm{~g}^{-1}$ at a scan rate of $20 \mathrm{mV} \mathrm{s}^{-1}$. The charge-discharge curve showed that the charge on the electrode remains for a longer period. Based on the above results, it is concluded that the electrodeposition is a suitable method to produce $\mathrm{Mn}-\mathrm{Ni}$ oxide films with a good specific capacitance.

It was observed that the cyclic voltammetric curves revealed one pair of redox peaks, suggesting the capacitive behavior of manganese-nickel oxide electrode. The observed anodic peak is due to the oxidation of $\mathrm{Ni}^{2+}$ and $\mathrm{Mn}^{2+}$ and cathodic peak is due to the reduction of $\mathrm{Ni}^{4+}$ and $\mathrm{Mn}^{4+}$. The smaller particle size with effective electroactive surface area of the electrode is responsible for the improved charge transfer performance of the oxide electrode. Direct deposition of oxide film over the substrate, which enhances electrical contact between active mass and substrate, is also responsible for the good electrochemical performance of the oxide electrode.

\section{REFERENCES}

1. Fabrication of $\mathrm{Ni}(\mathrm{OH})_{2}$ nanoflakes array on $\mathrm{Ni}$ foam as a binder-free electrode material for high performance supercapacitors / Hu B., Qin X., Asiri A.M., Alamry K.A., Al-Youbi A.O., Sun X. // Electrochim. Acta. - 2013. - Vol.107. - P.339-342.

2. Winter M., Brodd R.J. What are batteries, fuel cells, and supercapacitors? // Chem. Rev. - 2004. - Vol.104. - P. 42454270.

3. Lee H.Y., Goodenough J.B. Supercapacitor behavior with $\mathrm{KCl}$ electrolyte // J. Solid State Chem. - 1999. - Vol.144. P.220-223.

4. Hydrous manganese dioxide nanowall arrays growth and their $\mathrm{Li}^{+}$ions intercalation electrochemical properties / Liu D., Zhang Q., Xiao P., Garcia B.B., Guo Q., Champion R., Cao G. // Chem. Mater. - 2008. - Vol.20. - P.1376-1380.

5. Zheng J.P., Cygan P.J., Jow T.R. Hydrous ruthenium oxide as an electrode material for electrochemical capacitors // J. Electrochem. Soc. - 1995. - Vol.142. - P.2699-2703.

6. Enhanced supercapacitance of multiwalled carbon nanotubes functionalized with ruthenium oxide / Arabale G., Wagh D., Kulkarni M., Mulla I.S., Vernkar S.P., Vijamohanan K., Rao A.M. // Chem. Phys. Lett. - 2003. - Vol.376. - P.207-213.

7. Wang Y.G., Zhang X.G. Preparation and electrochemical capacitance of $\mathrm{RuO}_{2} / \mathrm{TiO}_{2}$ nanotubes composites // Electrochim. Acta. - 2004. - Vol.49. - P.1957-1962.

8. Synthesis and electrochemical properties of mesoporous nickel oxide / W. Xing, F. Li, Z.F. Yan, G.Q. Lu // J. Power Sources. - 2004. - Vol.134. - P.324-330.

9. Lin C., Ritter J.A., Popov B.N. Characterization of solgel-derived cobalt oxide xerogels as electrochemical capacitors // J. Electrochem. Soc. - 1998. - Vol.145. - P.4097-4103.

10. Pang S.C., Anderson M.A., Chapman T.W. Novel 
electrode materials for thin film ultracapacitors: comparison of electrochemical properties of sol-gel-derived and electrodeposited manganese dioxide // J. Electrochem. Soc. - 2000. - Vol.147. P.444-450.

11. Preparation of novel nano-composite $\mathrm{Ni}(\mathrm{OH})_{2} / \mathrm{USY}$ material and its application for electrochemical capacitance storage / L. Cao, L.B. Kong, Y.Y. Liang, H.L. Li // Chem. Commun. 2004. - Vol.14. - P.1646-1647.

12. Preparation of the novel nanocomposite $\mathrm{Co}(\mathrm{OH})_{2} /$ ultra stable Y zeolite and its application as a supercapacitor with high energy density / L. Cao, F. Xu, Y.Y. Liang, H.L. Li // Adv. Mater. - 2004. - Vol.16. - P.1853-1857.

13. Ни C.-C., Tsou T.-W. The optimization of specific capacitance of amorphous manganese oxide for electrochemical supercapacitors using experimental strategies // J. Power Sources. - 2003. - Vol.115. - P.179-186.

14. Ghaemi M., Binder L. Effects of direct and pulse current on electrodeposition of manganese dioxide // J. Power Sources. - 2002. - Vol.111. - P.248-254

Received 04.10.2019

\section{ЕЛЕКТРООСАДЖЕННЯ ШАРІВ МАНГАН- НІКЕЛЕВОГО ОКСИДУ ДЛЯ ВИКОРИСТАННЯ У СУПЕРКОНДЕНСАТОРАХ}

\section{П. Данієль Ніксон, К. Джозеф Кеннеді}

Шари манган-нікелевого оксиду були електроосаджені на підкладку з нержавіючої сталі з електроліту, що містив манган сульфат, нікель хлорид і неіоногенну поверхнево-активну речовину. Досліджені структурні, морфологічні та електрохімічні властивості иих шарів. Отримані рентгенівські діфрактограми дозволили визначити розмір кристалітів в матеріалі і підтвердити наявність оксидів мангану та нікелю. Такі параметри синтезу, як вікно потенціалів, швидкість сканування потенціалу, концентрація електроліту та кількість циклів, були оптимізовані методом потенціодинамічного осадження. Циклічна вольтамперометрія була використана для вивчення механізму відновлення $і$ окислення при електроосадженні оксидних шарів. Метод отримання розрядно-зарядних кривих був використаний для дослідження ємнісних властивостей синтезованого матеріалу.

Ключові слова: суперконденсатор, оксидний електрод, електроосадження, характеристики поверхні, циклічна вольтамперометрія, розрядно-зарядні криві.

\section{ELECTRODEPOSITION OF MANGANESE-NICKEL OXIDE FILMS FOR SUPERCAPACITOR APPLICATIONS}

\section{$P$. Daniel Nixon, C. Joseph Kennady *}

Karunya Institute of Technology and Sciences, Coimbatore, India

\section{* e-mail: kennady@karunya.edu}

Manganese-nickel oxide films were electrodeposited on a stainless steel plate substrate in a bath containing manganese sulfate, nickel chloride and a non-ionic surfactant. The structural, morphological and electrochemical properties of these films were investigated. The $X$-ray diffraction pattern revealed the grain size of the material and confirmed the presence of manganese oxide and nickel oxide in the films. The preparative parameters, such as potential window, scan rate, bath concentration and numbers of potential cycles, were optimized during potentiodynamic deposition. The cyclic voltammetry was used to study the reduction and oxidation mechanism during the electrodeposition process. The charge-discharge method was applied to study the capacitor property of the synthesized material.

Keywords: supercapacitor; oxide electrodes; electrodeposition; surface characterization; cyclic voltammetry; charge-discharge curve.

\section{REFERENCES}

1. Hu B., Qin X., Asiri A.M., Alamry K.A., Al-Youbi A.O., Sun $\mathrm{X}$. Fabrication of $\mathrm{Ni}(\mathrm{OH})_{2}$ nanoflakes array on $\mathrm{Ni}$ foam as a binder-free electrode material for high performance supercapacitors. Electrochimica Acta, 2013, vol. 107, pp. 339342 .

2. Winter M., Brodd R.J. What are batteries, fuel cells, and supercapacitors? Chemical Reviews, 2004, vol. 104, pp. 42454270 .

3. Lee H.Y., Goodenough J.B. Supercapacitor behavior with $\mathrm{KCl}$ electrolyte. Journal of Solid State Chemistry, 1999, vol. 144, pp. 220-223.

4. Liu D., Zhang Q., Xiao P., Garcia B.B., Guo Q., Champion R., Cao G. Hydrous manganese dioxide nanowall arrays growth and their $\mathrm{Li}^{+}$ions intercalation electrochemical properties. Chemistry of Materials, 2008, vol. 20, pp. 1376-1380.

5. Zheng J.P., Cygan P.J., Jow T.R. Hydrous ruthenium oxide as an electrode material for electrochemical capacitors. Journal of the Electrochemical Society, 1995, vol. 142, pp. 26992703.

6. Arabale G., Wagh D., Kulkarni M., Mulla I.S., Vernkar S.P., Vijamohanan K., Rao A.M. Enhanced supercapacitance of multiwalled carbon nanotubes functionalized with ruthenium oxide. Chemical Physics Letters, 2003, vol. 376, pp. 207-213.

7. Wang Yong-gang, Zhang Xiao-gang. Preparation and electrochemical capacitance of $\mathrm{RuO}_{2} / \mathrm{TiO}_{2}$ nanotubes composites. Electrochimica Acta, 2004, vol. 49, pp. 1957-1962.

8. Xing W., Li F., Yan Z.F., Lu G.Q. Synthesis and electrochemical properties of mesoporous nickel oxide. Journal of Power Sources, 2004, vol. 134, pp. 324-330.

9. Lin C., Ritter J.A., Popov B.N. Characterization of solgel-derived cobalt oxide xerogels as electrochemical capacitors. Journal of the Electrochemical Society, 1998, vol. 145, pp. $4097-$ 4103.

10. Pang S.C., Anderson M.A., Chapman T.W. Novel electrode materials for thin-film ultracapacitors: comparison of electrochemical properties of sol-gel-derived and electrodeposited manganese dioxide. Journal of the Electrochemical Society, 2000, vol. 147, pp. 444-450.

11. Cao L., Kong L.B., Liang Y.Y., Li H.L. Preparation of novel nano-composite $\mathrm{Ni}(\mathrm{OH})_{2} / \mathrm{USY}$ material and its application for electrochemical capacitance storage. Chemical Communications, 2004, no. 14, pp. 1646-1647.

12. Cao L., Xu F., Liang Y.Y., Li H.L. Preparation of the novel nanocomposite $\mathrm{Co}(\mathrm{OH})_{2}$ /ultra-stable $\mathrm{Y}$ zeolite and its application as a supercapacitor with high energy density. Advanced Materials, 2004, vol. 16, pp. 1853-1857.

13. Hu C.C., Tsou T.W. The optimization of specific capacitance of amorphous manganese oxide for electrochemical supercapacitors using experimental strategies. Journal of Power Sources, 2003, vol. 115, pp. 179-186.

14. Ghaemi M., Binder L. Effects of direct and pulse current on electrodeposition of manganese dioxide. Journal of Power Sources, 2002, vol. 111, pp. 248-254. 